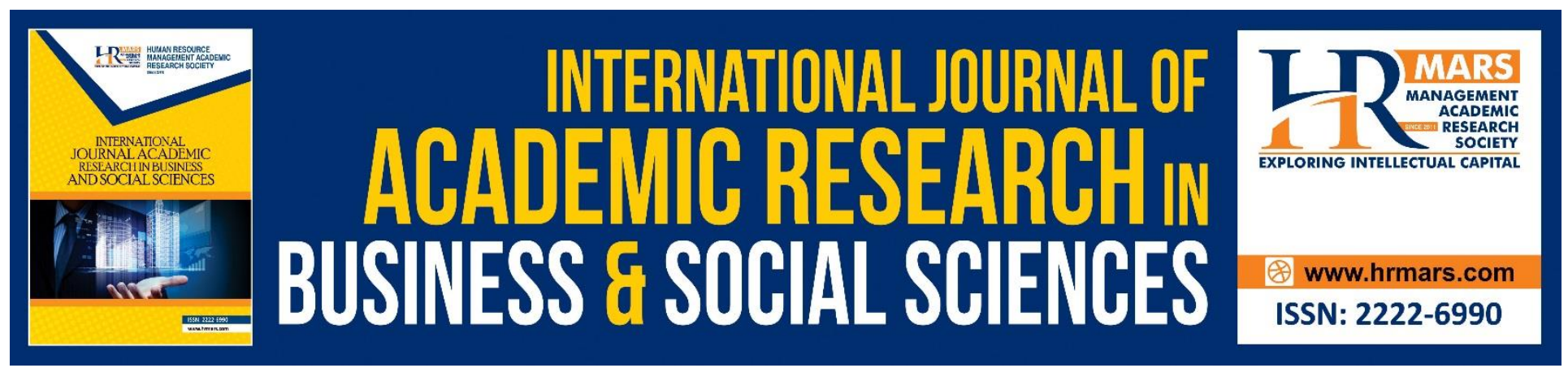

\title{
The Effect of Liquidity, Administrative Efficiency and Capital Adequacy on the Profitability of Jordanian Banks listed on the Amman Stock Exchange
}

\section{Mahmoud Ali Jaradat, Mohammad Hamdan Ali ALkhazaleh}

To Link this Article: http://dx.doi.org/10.6007/IJARBSS/v9-i1/5497

DOI: $\quad 10.6007 /$ IJARBSS/v9-i1/5497

Received: 12 Dec 2018, Revised: 21 Jan 2019, Accepted: 24 Jan 2019

Published Online: 08 Feb 2019

In-Text Citation: (Jaradat \& ALkhazaleh, 2019)

To Cite this Article: Jaradat, M. A., \& ALkhazaleh, M. H. A. (2019). The Effect of Liquidity, Administrative Efficiency and Capital Adequacy on the Profitability of Jordanian Banks listed on the Amman Stock Exchange. International Journal of Academic Research in Business and Social Sciences, 9(1), 998-1013.

\section{Copyright: (c) 2019 The Author(s)}

Published by Human Resource Management Academic Research Society (www.hrmars.com)

This article is published under the Creative Commons Attribution (CC BY 4.0) license. Anyone may reproduce, distribute, translate and create derivative works of this article (for both commercial and non-commercial purposes), subject to full attribution to the original publication and authors. The full terms of this license may be seen at: $\underline{\text { http://creativecommons.org/licences/by/4.0/legalcode }}$

Vol. 9, No. 1, 2019, Pg. 998 - 1013

Full Terms \& Conditions of access and use can be found at http://hrmars.com/index.php/pages/detail/publication-ethics 


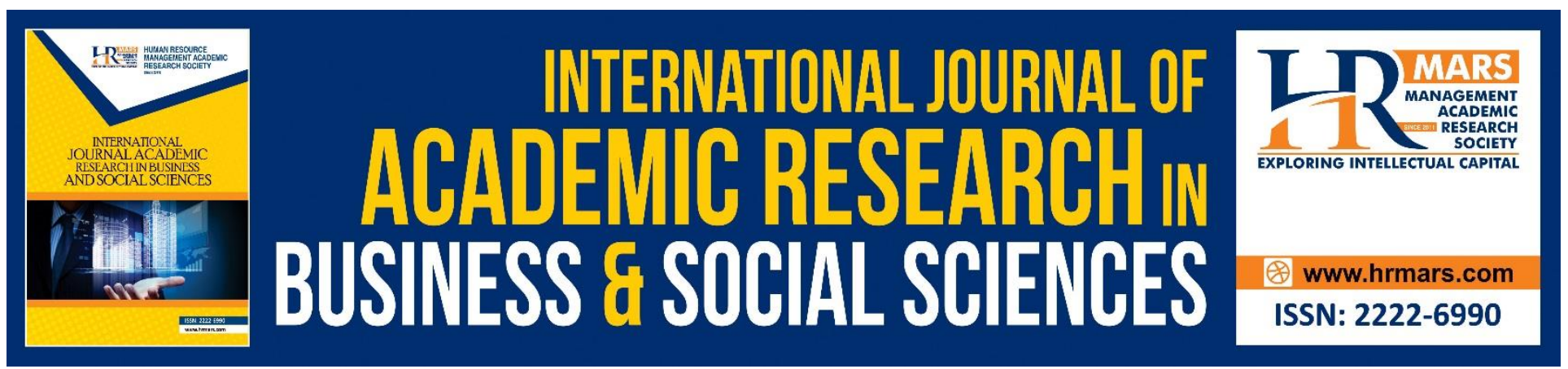

\title{
The Effect of Liquidity, Administrative Efficiency and Capital Adequacy on the Profitability of Jordanian Banks listed on the Amman Stock Exchange
}

\author{
Dr. Mahmoud Ali Jaradat \\ Facility of Economic and Administrative Sciences, Al-albayet university-Jordan
}

Mohammad Hamdan Ali ALkhazaleh

Al-albayet university-Jordan

\section{ABSTRACT}

This study aimed to examine the impact of liquidity, administrative efficiency and capital adequacy onthe profitability of Jordanian banks listed on the Amman stock exchange (AMS). The analytical descriptive approach was used to study the panel datamethod, and to rely on the random effect model. Thevariables of the study were liquidity, administrative efficiency and capital adequacy's independent variables, and profitability as dependent variable. The sample of the study is all of the Jordanian commercial banks(JCB) listed on the AMS, which number thirteen. To achieve the objective of the study the annual data on the variables affecting the profitability of banks for the period (2010 to 2016) were analyzed. The study found the following results: there is a significant impact of liquidity, administrative efficiencyandcapital adequacyon the profitability of Jordanian banks listed at the AMS. There is a negative impact of liquidity on the profitability of Jordanian banks listed at the AMS. There is a positive impact of administrative efficiency on the profitability of Jordanian banks listed at the AMS. There is no impact of capital adequacy on the profitability of Jordanian banks listed at the AMS.

Keywords: Liquidity, Administrative Efficiency, Capitaladequacy, Profitability.

\section{Introduction}

Commercial banks have an important position in the Jordanian economy because of their pioneering role in finance and investment. The banks seek to achieve profits by diversifying their investment and financing activities. These profits enable them to survive and maintain their financial position and improve their capital and liquidity, thus increasing their ability to face the risks and obligations they face. It was therefore necessary to highlight the most important factors affecting the profitability of Jordanian commercial banks. 


\section{Study Problem}

Profitability is one of the main objectives of all financial and banking institutions and is essential for their sustainability and is used as a benchmark for evaluating the performance of these institutions. However, commercial banks face the problem of finding a balance between the factors of liquidity, administrative efficiency and capital adequacy, which are the most influential factors on the profitability of the bank; therefore, the impact of these factors on profitabilitymust be discussed.

The importance of this study is to demonstrate the effect of(liquidity, administrative efficiency and capital adequacy) on the profitability of Jordanian commercial banks listed on the Amman Stock Exchange and to try to reach conclusions and recommendations which can help these banks to strengthen the factors that will maintain and increase profits.

\section{Study Objectives}

This study aims at identifying the effect of:

1. Liquidity on the profitability of Jordanian commercial banks listed on the Amman Stock Exchange.

2. Administrative efficiency on the profitability of Jordanian commercial banks listed on the Amman Stock Exchange.

3. Capital adequacy on the profitability of Jordanian commercial banks listed on the Amman Stock Exchange.

\section{Study Hypotheses}

By presenting the problem of the study and the objectives it seeks to achieve, the hypotheses of the study can be formulated as follows:

There is no statistically significant effect at the level of $(\alpha \leq 0.05)$ for liquidity, administrative efficiency and capital adequacy on the profitability of Jordanian commercial banks listed on the Amman Stock Exchange.

The following sub-hypotheses are derived from the main hypothesis:

1. There is no statistically significant effect at the level $(\alpha \leq 0.05)$ of liquidity on the profitability of Jordanian commercial banks listed on the Amman Stock Exchange.

2. There was no statistically significant effect at the level of significance $(\alpha \leq 0.05)$ for administrative efficiency on the profitability of Jordanian commercial banks listed on the Amman Stock Exchange.

3. There is no statistically significant effect at the level $(\alpha \leq 0.05)$ of capital adequacy on the profitability of Jordanian commercial banks listed on the Amman Stock Exchange.

\section{Literature Review}

Al-Zubaidi and Salamah (2010) examined the relationship between working capital management and profitability an analytical study on companies listed in the Saudi Financial Market for the period (2004 - 2009). The descriptive analytical method was used. The study reached several results. The leverage has a negative impact on the level of profitability in Saudi companies, and the study recommended 
the need to focus on identifying investment in commodity inventory according to the optimal rules for investment. Al-Tayeb and Shehatait (2011) analyzed the Application of Capital Adequacy on Commercial Banks' Profitability: The Case of Jordan. The objective of this study is to measure the effects of the application of commercial banks in Jordan to the capital adequacy criterion on their profitability. Data were used during the period (2000-2007). The study used the regression model based on the Panel data. The study concluded that the application of the capital adequacy criterion did not have a statistically significant effect on the profitability of commercial banks in Jordan or had a negative impact. There is a positive effect of raising capital on three ratios of profitability.

Maward and Shurooqi (2014) investigated the factors affecting the Profitability of Commercial Banks.The objective of the study was to analyze the effect of internal factors (liquidity, loans, indebtedness, equity, size of the bank, general expenses) on the profitability of commercial banks operating in Algeria. The study concluded that the private commercial banks are more efficient in achieving profits compared to public banks. There is no statistically significant correlation between the ratios of equity to total assets. Merhaj and others. (2014) aimed to determine the factors that affect the profitability of commercial banks, their ranking according to their relative importance, and comparison between commercial and public banks regarding the factors that affect their profitability. The study used the descriptive analytical method. The study reached a number of results which can be classified into two categories: internal factors, external factors, and the factors affecting the profitability of commercial banks vary in their relative importance, and the most influential factors were the economic and political conditions, the use of resources, legal legislation and controls for banking.

Al-Khansa and Dhaher (2015) aimed at showing the effect of liquidity and risk on the profitability of private banks operating in Syria, and the nature of this effect. The study problem was that there is an effect of liquidity and its risks on profitability in commercial banks operating in Syria and the nature of this effect. From 2008 to 2014, where the study data were collected mainly from the financial statements of the study used panel data analysis. The data was analyzed based on the EVIEWS 7 statistical program. Profitability was a dependent variable and both liquidity and liquidity risk were independent variables. The study found that the nature of the relationship between liquidity and profitability is a linear relationship for the studied banks, i.e., with each increase in the liquidity rate will lead to an increase in the negative impact on profitability. The study recommended that the management of liquidity to seek investment opportunities of good economic feasibility so that the excess liquidity is used in a manner that profits these banks and does not affect their ability to meet their obligations to depositors.

Fakhri and Kader (2016) aimed at identifying the effect of liquidity, capital, exchange rate, interest rate and inflation on the profitability of Iraqi commercial banks during the period 1998-2011. The study used the multiple linear econometrics model to show the effect of independent variables on the dependent variable. The study reached several results, including that the capital and interest rate of the most important variables affecting the profitability of banking, and that liquidity has a negative impact on profitability. Khalif \& Naji (2017) clarified the liquidity risks and their effect on the 
profitability of commercial banks using the annual audited financial statements of Iraqi commercial banks for the period 2008-2013. The applied methodology was used based on the research sample. The SPSS p18 was used to download the data, linear regression and correlations coefficient to prove the hypotheses of the study. The study showed many results. The most important was found to have a negative or inverse relation between the return on assets and the ratio of cash to assets and loans to deposits.

Khakani and Salah (2017) demonstrated the importance of the banking capital adequacy criterion in achieving banking stability, strengthening the financial position of the bank and indicating the relationship between the capital adequacy criterion and bank liquidity. During the period (2004 2014) and used the descriptive analytical method. The study concluded that the relationship was positive with a positive effect between capital adequacy and liquidity. The higher the capital adequacy ratio, the higher the bank's liquidity.

Karrar and Nouri (2017) measured the capital risk in banks and the extent of their ability to face and contain them to reduce their consequences for the future of the bank and to study and measure the bank profitability using its own indicators and to show their importance in the sustainability of banks. The study period was from 2010 to 2014. The study found that Cairo Amman Bank was the most profitable in the banking profitability indices compared to the Bank of Jordan, which shows that the bank has successful policies in managing and employing the funds it receives whether it is deposits or any source of financing. The study recommended reviewing the policies followed by the two banks in how to deal with their capital in terms of the right and useful employment in order to be positive in the interest of shareholders and depositors alike.

Berger (1995) examined the relationship between profitability and capital in US commercial banks during the period 1983-1989, where the multiple regression between capital and return on equity was used. Due to some changes in the laws and regulations relating to American commercial banks, the analysis was re-conducted for the period 1992-1995. The findings of this study indicate that there was a positive relationship between profitability and capital in commercial banks during 1983-1989. Between profitability and capital during 1992-1995.

Sulieman (2015) investigated the effect of liquidity management on profitability in Jordanian commercial banks during the period (2012-2015). The sample of the study included all commercial banks of 13 commercial banks. The ratio of fast liquidity, investment ratio, capital ratio and net credit facilities were independent variables, and both return on assets and return on equity were dependent variables. The study used the Augmented Dickey Fuller (ADF) test to test the root unit in a time series of the search variables, and the hypothesis was tested using regression analysis. The study found that the ratio of investment in available funds leads to increased profitability, and that the increase in the ratio of capital and the ratio of liquid assets leads to a decrease in profitability. The study recommended that there is a need to optimize the liquidity available in various aspects of investment in order to increase the profitability of banks. Banks should adopt a general liquidity management framework to ensure sufficient liquidity for the operation. 
Kosmidou and Pasiouras (2005) examined the determinants of the profitability of British banks during the period 1995-2002. The study used the method of natural regression analysis, the dependent variable was the rate of return on assets, the independent variables (cost to income ratio, cash liquidity to current assets, as measured by total assets). One of the main findings of the study was that the ratio of costs to income is negative with return on assets and that the ratio of cash to current assets is a positive relationship with return on assets but the ratio of current assets to total assets of the bank The study found that there is a positive relationship between profitability and the percentage of ownership, because the higher the percentage of ownership the less the need for external sources of financing, and the relationship Between the size of the bank and the return on assets was inverse, as large banks sought to reduce interest margins and thus lower profits.

Căpraru and Iulian (2014) examined the main determinants of profitability of banks in five Central and Eastern European countries during the period 2004 to 2011. The study sample included 143 commercial banks in Romania, Hungary, Poland, Czech Republic and Bulgaria. The variables were both return on assets and return on equity (The size of the bank, capital adequacy, credit risk, management efficiency, liquidity risk, MIX index) and external determinants (market concentration, inflation, economic growth). The study used data collection, the annual reports of the banks, and the sample of the study and the statistical database of the European Bank. For the data of economic growth and inflation, the World Bank database was used. The study reached several results, including that administrative efficiency and capital adequacy have a positive impact on the profitability of banks,And that the size of the bank has a negative impact on the net interest margin. The study recommended further supervision of credit risk, monitoring credit risk indicators and improving costs.

Waqas and Usman (2014) examined the effect of determinants and factors affecting the profitability of Pakistani commercial banks during the period 2004-2010. The study used the fixed effect model and the random effect model to discover the relationship between the variables. The data were collected from the annual reports of the sample banks and the Central Bank of Pakistan. Several previous studies have used ROR and net interest margin to measure profitability. The study sample consisted of 17 commercial banks in Pakistan. The profitability and the real interest rate were dependent variables, both capital and ratio Assets, size, deposits, credit and tax risks, interest expenses and asset quality are independent variables. The study reached many results. The most important of these was that the Pakistani banks face many problems which are challenging and therefore need time to determine the factors affecting their profitability. Money and volume have a positive impact on the rate of profitability where the greater the capital and the size of the bank led to higher profits.

Hamada and Kamaruzzaman (2015) aimed to know the effect of the capital structure on the profitability of family and non-family businesses listed on the Malaysian Stock Exchange. The sample consisted of 46 family and 46 non-family companies during the period 2009-2011. The independent variables represent the ratio of short-term debt to total assets, long-term debt ratio to total assets and ratio of debt to total assets to see the effect on the dependent variable. The study investigated the return on equity (ROE) to measure profitability. The analytical descriptive method was used, and 
INTERNATIONAL JOURNAL OF ACADEMIC RESEARCH IN BUSINESS AND SOCIAL SCIENCES

Vol. 9, No. 1, Jan, 2019, E-ISSN: 2222-6990 (C) 2019 HRMARS

the use of a multivariate model. The study reached many results, the most prominent of which was that high profit companies rely heavily on equity as a financing option, And the increase in financial leverage center negatively affects the profitability rate.

\section{Methodology}

\section{Study Method}

Through the study of previous studies it became clear that the appropriate approach to the study is the descriptive and analytical approach in order to take into account the various theoretical and practical aspects of the subject depending on the sources and references such as books, scientific articles and magazines, etc., in addition to statistical and standard tools to facilitate measurement of financial variables used in the model.

\section{Study Variables}

In order to estimate the "effect of liquidity, administrative efficiency andcapitaladequacy on the profitability of Jordanian banks listed on the Amman Stock Exchange", the study used the panel data method and was based on the Random Effect model according to the Hausman Test.

\section{Statistical Methods}

After obtaining the necessary data, and based on the previous studies, the appropriate statistical tests were used based on EVIEWS software, in order to answer the study questions and test hypotheses and then formulate the conclusions and recommendations and can be explained as follows:

1. Unit Root Testing (Unit Root)

Time seriesstationary test (root unit):

On the application level, there are several tests that can be used to test the stability of the series. The unit root test will be focused on the most common tests used in practical applications. On the premise that the limits of error are not intrinsically correlated and dropping this hypothesis leads to the problem of serial correlation.

First: the Dickey-Fuller test (Dickey-Fuller, 1979), the Augmented Dickey-Fuller test (1981).

Second: (Phillips and Perron, 1988).

Dickey-Fuller test (Dickey-Fuller, 1979), the Augmented Dickey-Fuller test:

The test of Dickey-Fuller is one of the most used tests in practical applications, and the content of this test. If the regression coefficient of the proposed standard formula is equal to one, this results in a unit root problem which means the instability of time series data $(p=1)$ The simple Dickey-Fuller is based on the assumption that the error limit is a white disturbance, that is, he did not consider the possibility of serial-correlation and this is the weakness of the test, so it was modified with theAugmented Dickey-Fuller test.

The Dickey-Fuller test composite test incorporates a number of time-gap differences until the serialcorrelation problem of the simple Dicky-Fuller test disappears. Thus, the proposed standard formula includes variables with slows as explanatory variables to eliminate the possibility of serial-correlation of the error term (Al-Rasheed, 2010). 
The ADF is tested on three specifications (specification-3), because the ADF distribution of critical values is affected by whether or not the constant exists:

1- Regression procedure with a constant presence and a general trend, which is the comprehensive model.

2- - Perform a slope with a constant presence only.

3- Perform a gradient without a constant or general orientation.

\section{Phillips and Perron Test (1988)}

This test is based on the introduction of a serial-correlation correction using a non-parameterized method. What distinguishes this test is that it takes into account the structural changes of the time series. It has a greater experimental power than the ADF test, as it differs from DF and ADF in that it contains slower values of differences Takes into account the first differences in the time series using Non-ParametricCorrelated and allows an average of zero and a linear trend of time that is not based on the distribution of the error term coefficient.

\section{Data Analysis (The Panel Data Analysis)}

The term "Panel data" is the data for time series and cross section data. In this context, Hsiao (1986) suggests that tabular data is, in general, an analysis of extended data. The advantages of using panel data are that they take into account individual differences, give more useful, varied data, less correlation between variables, a large number of degrees of freedom, and more efficient than time series that suffer from the problem of serial-correlation. Panel data also have the ability to define and measure unobserved effects in descriptive analysis and time series analysis (Baltagi, 2000).

\section{Panel Data Model}

$$
Y_{i t}=\beta X_{i t}+U_{i t} \ldots \ldots \ldots \text {....(1) }
$$

Where $Y$ is the dependent variable, $i$ is the unit, $t$ is the time, $X$ is the independent variable, $U$ is the error term that is not specified in this equation as it appears independent of both units $i$ and time $t$ (Worral and Pratt 2000).

In the analysis of panel data, it is possible to use the Fixed Effects Model or the Random Effects Model. The fixed effects model has constant trends over time, while the constant is different for each unit but constant over time, the constant reflects the characteristics of the units under test as these characteristics vary from unit to unit. For the random effects model, the slope is also constant over time, but the constant is random. This randomization is a function in the mean values plus the random limit. (Manez, Rochina, and Sanchis 2004).

The Hausman Test is used to select the appropriate test for the fixed effects model or the random effects model based on the probability value or the probability level of Chi-Square. If the value is less than $5 \%$ the fixed effects model is used, if the value is greater than $5 \%$ Random effects model is used. (Torres-Reyna, 2007).

\section{The Empirical Model}

This study uses the analysis of time series data (panel data) because the panel data is certainly the most appropriate because it takes into account changes over time of the performance indicators, and 
INTERNATIONAL JOURNAL OF ACADEMIC RESEARCH IN BUSINESS AND SOCIAL SCIENCES

Vol. 9, No. 1, Jan, 2019, E-ISSN: 2222-6990 (C) 2019 HRMARS

takes into account the different characteristics of each bank and the temporary changes in the banking environment (Bortolotti, D,Souza and Megginson, 2002).

\section{Study model}

ROAit $=\alpha i t+\beta_{1}$ Adcit $+\beta_{2}$ Liqit $+\beta_{3}$ Capit + eit............. (2)

Where:

ROAit: Return on assets

Adcit: Administrative competence

Liqit: Liquidity

Capit: capital adequacy

$\beta 1, \beta_{2}, \beta_{3}$ : parameters

$\varepsilon_{\text {it: }}:$ : Error term

\section{Study Population and Sample}

The study population includes Jordanian banks listed on the Amman Stock Exchange. The study sample includes all Jordanian commercial banks listed on the Amman Stock Exchange of 13 commercial banks until the end of 2016. Data on the study variables is collected from the annual reports of the banks surveyed and the data published on the Amman Stock Exchange for the period (2010-2016). According to the Banks Guide issued by the Central Bank of Jordan, Jordanian commercial banks consist of the banks listed in Table (2):

Table (2) Names of Commercial Banks until the end of 2016

\begin{tabular}{|l|l|l|}
\hline No. & Name of the Bank & Date of Establishment \\
\hline 1 & Arab Bank & 1930 \\
\hline 2 & Jordan National Bank & 1956 \\
\hline 3 & Bank of Jordan & 1960 \\
\hline 4 & Cairo Amman Bank & 1960 \\
\hline 5 & Housing Bank for Trade and Finance & 1974 \\
\hline 6 & Jordan Kuwait Bank & 1977 \\
\hline 7 & Jordan Commercial Bank & 1978 \\
\hline 8 & Arab Jordan Investment Bank & 1978 \\
\hline 9 & Arab Exchange Bank & 1989 \\
\hline 10 & Investment Bank & 1987 \\
\hline 11 & Union Bank & 1991 \\
\hline 12 & Sustie General Bank - Jordan & 1993 \\
\hline 13 & Jordan Financial Bank & 1996 \\
\hline
\end{tabular}

\section{Sources of Data Collection:}

The study relied on the following sources in data collection:

- Annual reports issued by Jordanian commercial banks.

- Data published on the Amman Stock Exchange. 
INTERNATIONAL JOURNAL OF ACADEMIC RESEARCH IN BUSINESS AND SOCIAL SCIENCES

Vol. 9, No. 1, Jan, 2019, E-ISSN: 2222-6990 (C) 2019 HRMARS

- Books, references, researches, previous studies, magazines and websites related to the subject of the study.

\section{Data Analysis and Hypothesis Testing}

After obtaining the necessary data, and based on previous studies, researchers used the appropriate statistical tests based on EVIEWS software, in order to answer the questions of the study and test hypotheses and then formulate the conclusions and recommendations, and can be clarified through the following stages:

\section{Time Series Stationary test (Unit Root Test)}

Numerous studies (Stock and Watson, 1988; Plosser\& Nelson, 1982) and Yule (1926) have shown that time series of financial variables are unstable resulting in Spurious Regression, The values of R2 are high even in the absence of a real relationship between the variables. Therefore, the stationary of the variables of the study must be verified by using the Unit Root Test by using the AugmentedDickey Fuller (ADF) or not contain the root of the unit so that the null hypothesis is to contain the string. The probability of the variable being determined on the basis of the unit is unstable. This hypothesis is judged by acceptance or rejection by observing the probability value. If it is less than (0.05), this means that the calculated value of the ADF is greater than the value of the ADF which indicates that the time series is stationary.

\section{Time Series Stationary Test for Study Variables}

In order to test the stability of the time series of the study variables, both the Augmented DickeyFuller and Phillips Peron tests were used to ascertain the stability of the time series. The non-stability of the time series results in spurious regression results. Thus, the tests were conducted for the study variables at the level in Table (3) the variables are not stationary at the level. Therefore, the first difference must be taken for all the variables and then re-test. After taking the first difference, it was determined by the tests (Augmented Dickey Fuller and Phillips Peron) and by the significant value which was less than $5 \%$ for bothteststhestationary of the time series of the data and thus reject the null hypothesis and accept the alternative hypothesis that the absence of the root of the unit, that is, the time series of the variables of the study became stable and this indicates that the impact of all temporary shocks will weaken over time in the long run especially since the test Phillips Peron takes into account Random errors are more comprehensive than the test (Dicky Fuller) and thus the data is ready for analysis. 
INTERNATIONAL JOURNAL OF ACADEMIC RESEARCH IN BUSINESS AND SOCIAL SCIENCES

Vol. 9, No. 1, Jan, 2019, E-ISSN: 2222-6990 (C) 2019 HRMARS

Table (3) Results of Unit-Root Test- Stationary Test

\begin{tabular}{|l|l|l|l|l|}
\hline \multicolumn{2}{|l|}{ Test } & \multirow{2}{*}{ Variables } \\
\cline { 1 - 1 } $\begin{array}{l}\text { PP-Fisher } \\
\text { Chi-sq }\end{array}$ & $\begin{array}{l}\text { ADF- Fisher } \\
\text { Chi-sq }\end{array}$ & \\
\cline { 1 - 3 } $\begin{array}{l}\text { Level } \\
\text { Prob }\end{array}$ & $\begin{array}{l}\text { 1rst Difference } \\
\text { Prob }\end{array}$ & $\begin{array}{l}\text { Level } \\
\text { Prob }\end{array}$ & $\begin{array}{l}\text { 1rst } \\
\text { Difference } \\
\text { Prob }\end{array}$ & \\
\hline 0.7783 & 0.0499 & 0.6857 & 0.0489 & Ade \\
\hline 0.5733 & 0.0001 & 0.6699 & 0.0027 & Liq \\
\hline 0.2172 & 0.0016 & 0.4770 & 0.0137 & Cap \\
\hline 0.6615 & 0.0072 & 0.7090 & 0.0452 & Roa \\
\hline
\end{tabular}

Source: Prepared by the researcher based on EVIEWS outputs.

To ascertain whether the variables are integrated first-class first, the researcher tested the degree of integration of residues.

Table (4) Stationary Test-Residuals Results

\begin{tabular}{|l|l|l|l|}
\hline \multicolumn{3}{|l|}{ Level } & Variables \\
\hline PP & ADF & Laggard & \\
\hline$* * * 0,000$ & $* * * 0,000$ & 2 & Z=resid \\
\hline
\end{tabular}

$* * *, * *, *$ indicates that the variables have remained at a significant level of $1 \%, 5 \%$ and $10 \%$, respectively.

Source: Prepared by the researcher based on EVIEWS outputs.

from Table (4) theresults ADF and PP tests show that the residuals are stationary at level. The absolute values of the estimated statistic were higher than those for all levels of the critical values, which rejects the null hypothesis that states that the residuals are not stationary and accept the alternative hypothesis that states that the residuals are stationary at level so the residuals integratedofl(0) at a significant level $1 \%$.

\section{Multicollinearity between Independent Variables:}

Before the multiple regression procedure, it is necessary to ensure that there is no high correlation between the independent variables. Table (5) shows the correlation results between the independent variables. The results show that there is no high correlation between the independent variables.

Table (5) Pearson Correlation Coefficient Results between Independent variables

\begin{tabular}{|l|l|l|l|}
\hline CAP & LIQ & ADC & \\
\hline 0.14 & -0.28 & 1 & ADC \\
\hline 0.27 & 1 & & LIQ \\
\hline 1 & & & CAP \\
\hline
\end{tabular}

Source: Preparation of the researcher based on EVIEWS outputs. 
INTERNATIONAL JOURNAL OF ACADEMIC RESEARCH IN BUSINESS AND SOCIAL SCIENCES

Vol. 9, No. 1, Jan, 2019, E-ISSN: 2222-6990 (C) 2019 HRMARS

In order to know the appropriate model of the estimate (the model of the fixed effect or the random effect model), we used the Hausman test. TheHausman test results were estimated in Table (6) the probability of Chi-Sq.Statistic is $(0.0921)$, which is greater than $5 \%$ Which states that the random effect model is appropriate and rejects the alternative hypothesis that the fixed effect model is appropriate.

Table (6) Hausmann Test Results

\begin{tabular}{|l|l|l|l|}
\hline & $\begin{array}{l}\text { Correlated Random } \\
\text { Effects }\end{array}$ & - Hausman Test \\
\hline & Test Cross-Section & \multicolumn{3}{l|}{ Random effects } \\
\hline Prob. & Chi-Sq.d.f. & Chi-Sq.Statistic & Test Summary \\
\hline 0.0921 & 3 & 6.439049 & $\begin{array}{l}\text { Cross-Section } \\
\text { Random }\end{array}$ \\
\hline
\end{tabular}

Source: Preparation of the researcher based on EVIEWS outputs.

\section{Study Hypotheses}

The hypotheses of the study were based on the study problem and the study questions as follows:

The main hypothesis: There is no statistically significant effect at $(\alpha \leq 0.05)$ level of liquidity, administrative efficiency and capital adequacy on the profitability of Jordanian commercial banks listed on the Amman Stock Exchange.

First Hypothesis: There is no statistically significant effect at the level of $(\alpha \leq 0.05)$ of liquidity on the profitability of Jordanian commercial banks listed on the Amman Stock Exchange.

Second Hypothesis: There is no statistically significant effect at the level of significance $(\alpha \leq 0.05))$ of administrative efficiency on the profitability of Jordanian commercial banks listed on the Amman Stock Exchange.

Third Hypothesis: There is no statistically significant effect at the level of $(\alpha \leq 0.05)$ of the capital adequacy on the profitability of Jordanian commercial banks listed on the Amman Stock Exchange.

\section{Analysis Results}

Study Model:

ROAit $=\alpha i t+\beta_{1}$ Adcit $+\beta_{2}$ Liqit $+\beta_{3}$ Capit $+\varepsilon i t$.

In order to test the hypothesis, the random effect model was used between independent and dependent variables based on the Hausman test Table (6).

Table 7 shows the following:

Through the value of the adjusted $R$ square (0.92), There is a statistically significant effect at the level of significance $(\alpha \leq 0.05)$ for liquidity, administrative efficiency and capital adequacy on the profitability of Jordanian commercial banks listed on the Amman Stock Exchange

Thus, the main hypothesis that there is no statistically significant effect at the level of $(\alpha \leq 0.05)$ of liquidity, administrative efficiency and adequacy on the profitability of Jordanian commercial banks listed on the Amman Stock Exchange is rejected, and the alternative hypothesis is accepted with a 
statistically significant effect at the level $(\alpha \leq 0.05)$ for liquidity, administrative efficiency and capital adequacy on the profitability of Jordanian commercial banks listed on the Amman Stock Exchange. As shown by the value of $F(135.8007)$ (0.0000), the model is valid for measuring the causal relationship of the independent variables to the dependent variable

As for the results of Table (7), there is a negative and significant effect of liquidity on the profitability of Jordanian commercial banks listed on the Amman Stock Exchange. The value of the coefficient is $(-0.29)$ and the significant level value $(0.0000)$ are less than $5 \%$ so we reject the null hypothesis, which states that there is no statistically significant effect at the level of $(\alpha \leq 0.05)$ of liquidity on the profitability of Jordanian commercial banks listed on the Amman Stock Exchange, and accept the alternative hypothesis of a significant statistical impact at the level of significance $(\alpha \leq 0.05)$ for liquidity on the profitability of Jordanian commercial banks listed on the Amman Stock Exchange Financial.

The results of Table (7) show that there is a positive and significant effect of administrative efficiency on the profitability of Jordanian commercial banks listed on the Amman Stock Exchange. The value of the coefficientis( 0.04 )and the significant level value is( 0.0000). This value is less than $5 \%$ The second sub-hypothesis, which states that there is no statistically significant effect at the level of ( $\alpha$ $\leq 0.05$ ) of administrative efficiency on the profitability of Jordanian commercial banks listed on the Amman Stock Exchange, and the acceptance of the alternative hypothesis with a statistically significant effect at the level of significance $(\alpha \leq 0.05)$ for administrative competence on the profitability of Jordanian commercial banks Listed on the Amman Stock Exchange.

The results of Table (7) show that there is no significant effect of the capital adequacy on the profitability of Jordanian commercial banks listed on the Amman Stock Exchange, where the value of the significant level is (0.5309) and this value is greater than $5 \%$, and thus accept the third hypothesis that states that there is no statistically significant effect at the level of $(\alpha \leq 0.05)$ of the capital adequacy on the profitability of Jordanian commercial banks listed on the Amman Stock Exchange. The alternative hypothesis was rejected with a statistically significant effect at the level of $(\alpha \leq 0.05)$ of the capital adequacyon the profitability of Jordanian commercial banks listed on the Amman Stock Exchange Financial.

Table (7) Results of Multiple Regression Analysis

\begin{tabular}{|c|c|c|c|c|}
\hline & & \multicolumn{3}{|l|}{$\begin{array}{l}\text { Dependent Variable: } \\
\text { ROA }\end{array}$} \\
\hline & & Method: Panel EGLS & \multicolumn{2}{|c|}{$\begin{array}{l}\text { (Cross-section } \\
\text { random effects) }\end{array}$} \\
\hline & & \multicolumn{3}{|c|}{$\begin{array}{l}\text { Date: } \quad 03 / 24 / 18 \\
\text { Time: 09:36 }\end{array}$} \\
\hline Prob. & t-Statistic & Std. Error & Coefficient & Variable \\
\hline 0.0496 & 2.042841 & 1.735970 & 3.546311 & $\mathrm{C}$ \\
\hline 0.0000 & 21.06012 & 0.002103 & 0.044297 & $A D C$ \\
\hline 0.0000 & -18.71119 & 0.015621 & -0.292300 & $\mathrm{LIQ}$ \\
\hline 0.5309 & -0.633677 & 0.012728 & -0.008065 & CAP \\
\hline 135.8007 & \multicolumn{2}{|l|}{ F-statistic } & 0.929289 & R-squared \\
\hline 0.000000 & \multicolumn{2}{|l|}{ Prob(F-statistic) } & 0.922446 & Adjusted R-squared \\
\hline
\end{tabular}

Source: Preparation of the researcher based on EVIEWS outputs. 
INTERNATIONAL JOURNAL OF ACADEMIC RESEARCH IN BUSINESS AND SOCIAL SCIENCES

Vol. 9, No. 1, Jan, 2019, E-ISSN: 2222-6990 @ 2019 HRMARS

\section{Conclusions and Recommendations}

\section{Results}

The results show that:

1- The value of the adjusted $R$ square is (0.92) has a statistically significant effect at $(\alpha \leq 0.05)$ for liquidity, administrative efficiency and capital adequacy on the profitability of Jordanian commercial banks listed on the Amman Stock Exchange.

2- The existence of a negative and significant effect of liquidity on the profitability of Jordanian commercial banks listed on the Amman Stock Exchange, where the value of the coefficient is $(-0.29)$ and the value of the significant level is $(0.0000)$ and this value is less than $5 \%$, thus rejecting the first hypothesis that states that there is no statistically significant effect at the level of $(\alpha \leq 0.05)$ of liquidity on the profitability of Jordanian commercial banks listed on the Amman Stock Exchange, and acceptance of the alternative hypothesis with a statistically significant effect at the level of ( $\alpha \leq 0.05$ ) on Jordanian Commercial Banks listed on the Amman Stock Exchange. This result is consistent with the study of Fakhri and Qadir (2016), Moheisen (2006), Al-Khansa and Dhaher (2015), AlSayegh and Abu Ahmad (2006).

3- There is a positive and significant effect of administrative efficiency on the profitability of Jordanian commercial banks listed on the Amman Stock Exchange. The value of the coefficient is (0.04) and the significant level value is (0.0000). This value is less than $5 \%$ The second sub-hypothesis, which states that there is no statistically significant effect at the level of ( $\alpha \leq 0.05$ ) of administrative efficiency on the profitability of Jordanian commercial banks listed on the Amman Stock Exchange, and the acceptance of the alternative hypothesis with a statistically significant effect at the level of significance ( $\alpha \leq$ $0.05)$ for administrative efficiency on the profitability of Jordanian commercial banks Listed on the Amman Stock Exchange. This result is consistent with al-Tai and Abdulhadi Study (2013), Al-Ghuson (2014), Abu Hassan (2006) and Bogdan and Julian (2014).

4- There is no significant effect of the capital adequacy on the profitability of Jordanian commercial banks listed on the Amman Stock Exchange, where the value of the significant level is (0.5309) and this value is greater than $5 \%$, and thus accept the third hypothesis that states that there is no statistically significant effect at the level of $(\alpha \leq 0.05)$ of the capital adequacy on the profitability of Jordanian commercial banks listed on the Amman Stock Exchange. The alternative hypothesis was rejected with a statistically significant effect at the level of $(\alpha \leq 0.05)$ of the capital adequacy on the profitability of Jordanian commercial banks listed on the Amman Stock Exchange Financial. This finding is consistent with the study of Shahatit and Al-Tayeb (2011); while not consistent with the study of Abu Fakhra (1997) and Fakhri\&Qader (2016),Khraiwish\&Seyam(2002), Berger and Mester(2003), Anderson (2008), Joen and Miller (2003), Pilluff and Rohades (2002), Dick (2006) and Trujillo-Ponce (2013). 
INTERNATIONAL JOURNAL OF ACADEMIC RESEARCH IN BUSINESS AND SOCIAL SCIENCES

Vol. 9, No. 1, Jan, 2019, E-ISSN: 2222-6990 (C) 2019 HRMARS

\section{Recommendations}

Based on the above findings, the study recommends the following:

1- Maintaining the level of administrative efficiency of Jordanian commercial banks and improving them by holding training courses that improve employee productivity and reduce expenses through better management of the bank's assets.

2- Jordanian commercial banks should focus on managing liquidity well, by aligning the profitability target with the objective of maintaining sufficient liquidity.

3- The capital adequacy ratio shall be maintained in accordance with the instructions issued by the Central Bank of Jordan, so as not to exceed substantially the percentage specified and not less than.

To carry out more studies and research in a broader period of time and space and to include all Jordanian and non-Jordanian commercial banks listed on the AmmanStock Exchange.

\section{References}

Al-Khansa, H. and Zaher, K. (2015), The Effect of Liquidity and its Risks on the profitability of banks An applied study on private commercial banks operating in Syria. Tishreen University Journal, 37 (5). Al-Sayegh, M. J., and Abuhamad, R. S. (2006), An Analytical Study of the Banking Liquidity of a Sample of Jordanian Commercial Banks. Iraqi Journal of Administrative Sciences, 3 (11), University of Karbala.

Alshatti, A. S. (2015). The Effect of the Liquidity Management on Profitability in the Jordanian Commercial Banks. International Journal of Business and Management,10(1),62-71.

Berger, A. N. (1995). The Relationship between capital and Earnings in Banking.Journal of Money Credit and Banking, 27(2), 432-456.

Capraru, B. \& Iulian, I. (2014). Banks' Profitability in Selected Central and Eastern European Countries. Journal Procedia Economics and Finance, 16, 587-591.

Dickey, D. A. and Fuller, W. A. (1979). Distribution of the estimators for Autoregressive time series with unit root. Journal of American statistical Association, 74, 427-431.

Dickey, D. A. and Fuller, W. A. (1981). Likelihood ratio statistics for Autoregressive time series with unit root. Economtrica, 49(4), 1057.

Baha Al-Din, F., and Qadir, S., (2016), Bank profitability index and the factors influencing it, a standard study in a sample of Iraqi commercial banks. Journal of Kirkuk University for Administrative and Economic Sciences, 6 (2).

Johansen, S. (1995). Likelihood-Based Inference in Cointegrated Vector Autoregressive Models, New York: Oxford University Press.

Karar, B. and Nouri, A. (2017), Use of Capital Risk Indicators in Assessing Bank Profitability- A Comparative Study between Jordanian and Amman Banks. Journal of Babylon University of Banking and Applied Sciences, 25 (1), Iraq.

Khakani, S., and Nouri, A. (2017), Analysis of the Effect of Capital Adequacy on Banking Liquidity. An applied study of a sample of Iraqi banks. Journal of the Faculty of Management and Economics for Economic, Administrative and Financial Studies, 9 (3), University of Babylon, Iraq. 
INTERNATIONAL JOURNAL OF ACADEMIC RESEARCH IN BUSINESS AND SOCIAL SCIENCES Vol. 9, No. 1, Jan, 2019, E-ISSN: 2222-6990 @ 2019 HRMARS

Kosimidou, K., Tanna, S. and Pasiouras, F. (2005). Determinants of profitability of domestic UK commercial banks: Panel evidence from the period 1995-2002. Applied Research Working Paper Series, Coventry University.

Merhaj, M., Adel, M., and Sameer, W. (2014), Determining factors affecting the profitability of commercial banks using multivariate analysis. Field study in the Commercial Bank of Syria in Lattakia Governorate. Tishreen University Journal, 36 (2).

Naji, K. and Hamad, A. (2017) Liquidity Risk and its Impact on the profitability of Commercial Banks An applied study on a sample of commercial banks in Iraq. Journal of Baghdad College of Economic Sciences, (52), Iraq.

Nelson, C. and Plosser, C. (1982). Trends and Random Walks in Macroeconomic Time Series: Some Evidence and Implications. Journal of Money Economics, 10.

Phillips, P.C. and Perron, P. (1988). Testing for a Unit Root in Time Series Regression. Biometrica, 75, 335-346.

Shahatit, S. and Al-Tayeb, M. (2011), A Standard Analysis of the Application of Capital Adequacy on the profitability of Commercial Banks: The Case of Jordan. Journal of Administrative Sciences, University of Jordan, 38 (2).

Yule, G.U. (1926). Why Do We Some Times Get Nonsense-Correlations Between Time-Series? A Study in Sampling and the Nature of Time-Series. Journal of the Royal Statistical Society, 89.

Zubaidi, H. and Salama, H. (2010), Relationship between the management of working capital and profitability. Analytical study on companies listed in the Saudi financial market for the period 2004 2007. Journal of King Abdul Aziz University, 26 (2).

Zinedine, M. (2014), Factors affecting the profitability of commercial banks - An empirical study on a sample of commercial banks operating in Algeria during the period (2005-2011). Algerian Journal of Economy and Finance, (1), Algeria.

Waqas, U. and Haseeb, A. (2014). Determinants of Commercial Banks Profitability: Empirical Evidence from Pakistan. International Journal of Accounting and Financial Reporting, 4(2), 1-22. 